\title{
A Case of Choledochal Cyst complicated by Acute Pancreatitis with Choledocholithiasis
}

\author{
Akmat Ali ${ }^{1 *}$, Richmond Ronald Gomes ${ }^{2}$ \\ ${ }^{I}$ Professor, Hepatology, Ad-din Women's Medical College Hospital, Dhaka, Bangladesh \\ ${ }^{2}$ Associate Professor, Medicine, Ad-din Women's Medical College Hospital, Dhaka, Bangladesh
}

\begin{abstract}
Choledochal cysts are dilatations of biliary tree that causes a diversity of clinical symptoms $\&$ lead to several complications. Choledochal cysts are most usually diagnosed in childhood \& frequently present with abdominal pain, jaundice and abdominal mass. Albeit the most concerning complication is malignancy. Other complications are stone formation, acute pancreatitis. Stricture may also occur \& can lead to morbidity. Treatment goal is not only relieving patient symptoms but also decreasing long term cancer risk. Here we present a young child presenting with abdominal pain \& vomiting secondary to type $1 \mathrm{~b}$ choledochal cyst complicated by acute pancreatitis with choledocholithiasis.
\end{abstract}

Keywords: Choledochal cyst, acute pancreatitis, Choledocholithiasis, malignancy.

\section{Introduction}

Choledochal cysts are rare congenital dilatation of extra hepatic \& or intra hepatic bile ducts. The incidence of choledochal cyst in Asian population has been reported to be 1 in 13,000 and 1:1000 in Japan [1]. Female are more frequently affected than male with a ratio 4:1 [2]. Although Choledochal cyst predominantely are diagnosed in children, about $25 \%$ of patient's diagnosis is delayed until adulthood [3].

Choledochal cyst causes a variety of clinical presentation \& can lead to several types of complications. It can be diagnosed by chance or serendipitously due to complications such as acute pancreatitis [4,5], choledocholitiasis. Early diagnosis \& treatment of choledochal cyst are crucial as they carry malignant potential that increases with age.

\section{Case Description}

An 18 month old female child presented at pediatric department with the complaints of eruptive vomiting for 3 days and abdominal pain for same duration. Pain appeared to be cramping \& intermittent, relived by lapping. On physical examination, body weight $9 \mathrm{~kg}$, height $79 \mathrm{~cm}$, ( WAZ: on $3^{\text {rd }}$ centile, WHZ: on $3^{\text {rd }}$ centile), icteric, irritable. Patient had significant sensitivity in abdomen.

Laboratory data showed the following values: $\mathrm{Hb}-8.4 \mathrm{~g} / \mathrm{l}$, microcytic hypochromic anemia, WBC- $8.2 \times 10 \wedge 3 / \mathrm{mL}$, S.bil- -irubin was $3.9 \mathrm{mg} / \mathrm{dl}$ with dominant direct bilirubin, SGPT 349 U/L, Anti HAV IgM: negative.

Serum amylase 306u/l, S. lipase 2270 U/L, electrolyte was normal. Abdominal USG showed-fusiform dilatation of $\mathrm{CBD}$ measuring about $(4.1 \times 1.7 \mathrm{~cm})$ cystic duct dilated. There were multiple granules mobile echogenic structure without shadow seen in lumen of the CBD. MRCP showed fusiform dilatation $(2.2 \mathrm{~cm})$ of proximal CBD involving common hepatic duct over $3.5 \mathrm{~cm}$ segment (Figure 1).

Distal CBD was mildly $(1 \mathrm{~cm})$ dilated containing 2 tiny flow void suggesting calculus $(0.5 \mathrm{~cm})$ seen with lumen of distal CBD (Figure 2). Pancreatic duct was visualized \& mildly dilated.

Corresponding Author: Richmond Ronald Gomes, Associate Professor, Hepatology, Medicine, Ad-din Women's Medical College Hospital, Dhaka, Bangladesh. Received date: February 07, 2021; Accepted date: February 15, 2021; Published date: February 16, 2021.

DOI: https://doi.org/10.31546/2732-5652.1003 


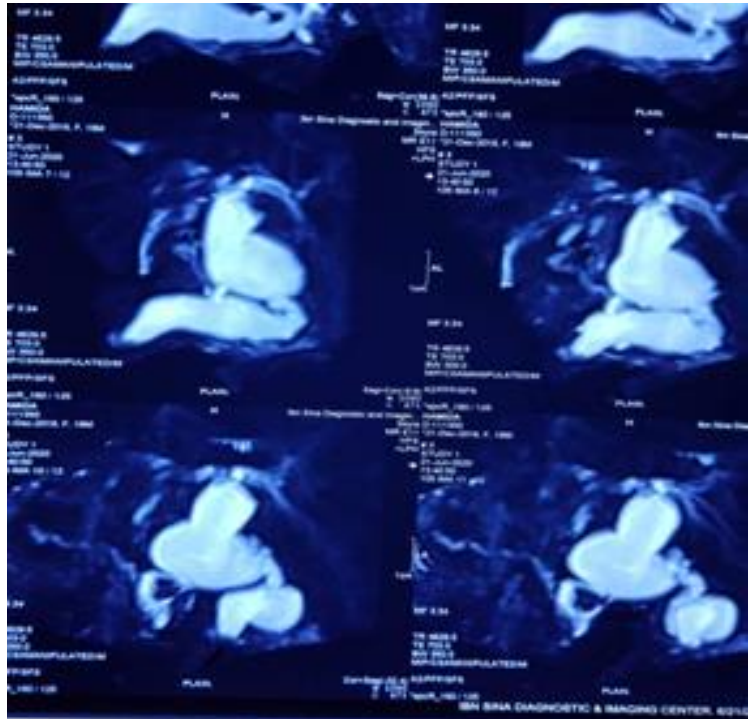

Figure 1: MRCP showing fusiform dilatation of proximal CBD involving common hepatic duct.

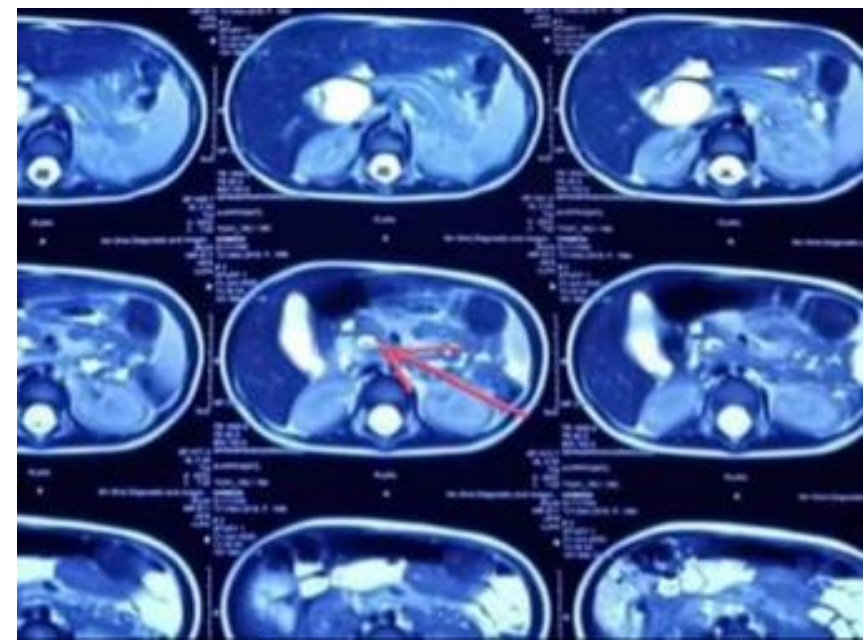

Figure 2: Distal CBD with signal void structure within suggestive of stones.

Thus the final diagnosis with acute pancreatitis with Choledocholithiasis caused by choledochal cyst type $1 \mathrm{~b}$ was made. Fluid resuscitation was given initially due to profuse vomiting. Other treatment included parenteral antiemetic, proton pump inhibitor, opiate analgesic. After treatment, patient showed significant clinical improvement with decreased frequency of vomiting. Intensity of abdominal pain was also decreased. She was planned to undergo definite treatment by surgery. After complete resolution of $1^{\text {st }}$ episode of pancreatitis the patient was operated 2 month later. The cyst was completely excised and cholecystectomy (Figure-3) and hepaticoduodenostomy were performed. Histopathology showed inflamed structure lined with biliary epithelium, free of any malignant lesion. The patient made an uneventful postoperative recovery.

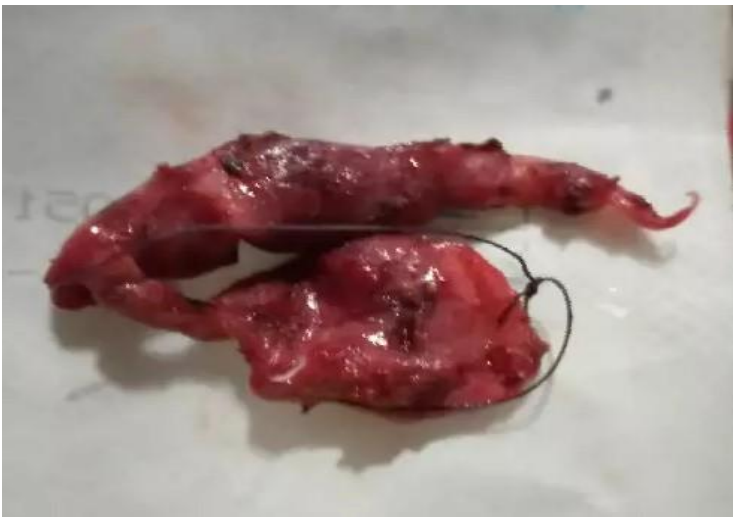

Figure 3: Resected common bile duct cyst \& gallbladder.

\section{Discussion}

Vater and Ezler (1723) defined Choledochal cyst as a congenital dilatation of extra \& / or intrahepatic bile duct. Pathophysiology remains still mysterious. The most widely accepted hypothesis is abnormal biliopancreatic junction [6]. Our patient has no such abnormality.

Anomalous Pancreaticobiliary Ductal Union (APBDU) allows reflux of pancreatic enzyme into biliary tree with consequent biliary duct inflammation predisposing to abnormal dilatation [7,8]. Some studies reported that sphincter of oddi dysfunction may predispose to Choledochal cyst [9]. Choledochal cyst may be part of congenital anomaly of biliary system or multiple conginatal anomaly proposed by some other expert $[10,11,12]$.

According to modified Todani classification (Figure). Choledochal cyst are classified into 5 types [13]. Clinical feature is variable \& may depend on patient age. Frequently observed symptom in infant is jaundice and abdominal pain as in adult [14]. Classic triad consisting of jaundice, abdominal pain and palpable mass would only be found in 15 to $25 \%$ case [15]. Our case, patient had jaundice and abdominal pain. Potential complications of this malformation include acute pancreatitis, ascending cholangitis, cholecystitis, cholelithiasis, biliary cirrhosis and cholangiocarcinoma have been reported [7]. Choledochal cyst in adult are often associated with complication compared to children has been reported [16].

The occurance of pancreatobiliary complications were to be brought by biliary stasis. This causes stone \& sludge formation that lead to bile duct \& pancreatic duct obstruction and resultanting pancreatitis [18]. 
Acute pancreatitis is a common complaint of adult patient. Acute pancreatitis is rare occurrence in patient with type 1 choledochal cyst \& just a couple of cases have been reported in the literature. Only $9 \%$ of pediatric patient with choledochal cyst were reported to have choledolithiasis [18]. In this patient diagnosis of pancreatitis was based on abdominal pain and high level of amylase. To our Knowledge the current patient is the youngest person with concomitant acute pancreatitis with choledocholithiasis which is rare.

Different imaging technique USG, MRI (MRCP), CT are available for the determination of choledochal cyst [19]. MRCP is considered the gold standard for diagnosis of biliary cyst with sensitivity 90-100\% [20]. Appropriate management consists of conservative treatment of complications followed by definitive surgery [16,17]. Saluja et al found that cyst excision with biliary reconstruction is necessary to prevent the recurrence of complication16. Now a days, complete resection of the cyst with cholecystectomy \& biliary reconstruction (RYHJ or HD) is considered the treatment of choice [21]. This operation was successful in our patient with no post-operative complication.

There are small numbers of studies in the literature on the pancreatic complication of choledochal cyst in children. Fujishiro et al [22], stated that pre-operative pancreatitis was most commonly seen in children with choledochal cyst type a.

To date, couples of studies have discussed the optimal timing of surgery for choledochal cyst complicated with acute pancreatitis in children. Cho et al proposed that early cyst excision after development of acute pancreatitis in patient with choledochal cyst reduced patient symptoms, especially occurrence of pseudopancreatis [23]. However deciding the timing of surgery in choledochal cyst complicated with pancreatitis is challenging. Here we report our experience in treating type $1 \mathrm{~b}$ choledochal cyst with acute pancreatitis with choledocholithiasis [24].

\section{Conclusion}

Congenital cystic dilatation of biliary tract is a rare anomaly that may stay quiet or uncovered by acute pancreatitis. The diagnosis is based on USG \& MRCP. Early diagnosis and prompt treatment is required to prevent long term complications. Acute pancreatitis is a uncommon occurrence in patient with type 1 choledochal cyst. Our patient with choledochal cyst associated with pancreatitis with choledocholithiasis was treated surgically with uneventful clinical outcome.

\section{Conflicts of Interest}

The authors declare no conflict of interest.
Patient Consent: Written informed consent was obtained from the patient for the publication.

\section{References}

1. O'Neill JA Jr. Choledochal cyst. Curr Probl Surg. 1992;29:361-410.

2. Wong-Hoi S, Chung HY, Lan LCL, et al. Management of choledochal cyst: 30 years of experience and results in a single center. J Pediatr Surg. 2009;44:2307-2311.

3. Liu CL, Fan ST, Lo CM, et al. Choledochal cysts in adults. Arch Surg. 2002;137:465-468.

4. Ahmed A, Nazlae Z, Fatine El A, et al. Kyste du choledoque rompu:revue de la literature. [Cyst of the broken common bile duct: literature review]. Pan Afr Med J. 2019;33:276.

5. Kabbaj N, et al. Apropos of a case of acute pancreatitis revealing cystic dilatation of common bile duct.Journal de radiologie.1998;79:13931397.

6. Ponce J, Garrigues V, Sale T, et al. Endoscopic biliary manometry in patients with suspected sphincter of oddi dysfunction and in patients with cystic dilatation of bile ducts. Dig Dis Sci. 1989;34:367-371

7. Bouali O, Trabanino $\mathrm{C}$, Abbo $\mathrm{O}$, et al. Biliary peritonitis after traumatic rupture of a choledochal cyst. Arch Pediatr. 2015;22:763-766.

8. Babbitt DP. Congenital choledochal cysts:new etiological concept based on anomalous relationships of common bile duct and pancreatic bulb. Ann Radiol (Paris). 1969;12:231-240.

9. Babbitt DP, Starshak RJ, Clemett AR. Choledochal cyst:a concept of etiology. Am J Roentgenol Radium Ther Nucl Med. 1973;119:5762.

10. Ponce J ,Ganrigues V Sale T, et al. Endoscopic biliary manometry in patients with suspected sphincter of oddi dysfunction and in patients with cystic dilatation of the bile ducts. Dig Dis Sci. 1989;34:367-371.

11. Goldman M, Pranikoff T. Biliary disease in children. Curr Gastroenterol Rep. 2011;13:193201.

12. El Mouhadi S, Arrive L. Choledochal cyst. Gastroenterol Clin Biol 2010:34:347. Epub 2010 May 27.

13. Brancatelli G, Federle MP, Vilgrain V, et al. Fibropolycystic liver disease: CT and MR imaging findings Radiographics. 2005;25:659-670. 
14. Todani T, Watanabe Y, Toki A, Morotomi Y. Classification of congenital biliary cystic disease: special reference to type $1 \mathrm{c}$ and $1 \mathrm{Va}$ cysts with primary ductal stricture. J Hepatobiliary Pancreat Surg. 2003;10:340-344.

15. Faik M, et al. Dilatation kystique du choledoque. a propos de 8 cas. 1999; 75:23-27.

16. Bouali O, Trabanino $\mathrm{C}$, Abbo $\mathrm{O}$, et al. Biliary peritonitis after traumatic rupture of a cholrdochal cyst. Arch Pediatr. 2015;22:763-766.

17. Saluja SS, Nayeeem M, Sharma BC, et al. Management of choledochal cysts and their complications. Am Surg 2012;78:284-290.

18. Singham J, Yoshida EM, Scudamore CH. Choledochal cysts: diagnosis. Can J Surg 2009;52:506-511.

19. Matsumoto Y, Uchida K, Nakase A, Honjo I. Congenital cystic dilatation of the common bile duct as a cause of primary bile duct stone. Am J Surg.1977;134:346-352.
20. Yu J, Turner MA, Fulcher As, Halvorsen RA. Congenital anomalies and normal varients of pacreaticobiliary tract and the pancreas in adults: part 1, Biliary tract. AJR Am J Roentgenol 2006; 187:1536-1543.

21. Park DH, Kim MH, Lee SK, et al. Can MRCP replace the diagnostic role of ERCP for patients with choledochal cysts? Gastrointest Endosc. 2005;62:360-366.

22. Patil V, Kanetkar V, Talpallokar MC. Hepaticoduodenostomy for biliary reconstruction after surgical resection of choledochal cyst: A 25 year experience. Indian J Surg. 2015;77(Suppl 2):240-244.

23. Fuishiro J, Masumoto K, Urita Y, et al. Pancreatic complications in pediatric choledochal cysts. J Pediatr Surg. 2013;48:1897-1902.

24. Cho MJ, Kim DY, Kim SC, et al. Delayed surgery for choledochal cyst with acute pancreatitis in children. Hepatogastroenterology. 2011;58:709712 . 